\title{
LATHYRUS SAXATILIS, A NEW SPECIES FOR ROMANIA
}

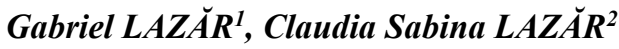 \\ ${ }^{1}$ National Institute for Research and Development in Forestry „Marin Drăcea” - Brașov Department, \\ 13 Cloșca Street, RO-500040 Brașov, Romania \\ 27 Spătarul Nicolae Milescu Alley, RO-500041 Brașov, Romania \\ e-mail: gabi_e_1@yahoo.com
}

\begin{abstract}
During botanical observations made in the spring of 2021, in the area of Enisala Nature Reserve (Tulcea County), the species Lathyrus saxatilis (Fabaceae) was discovered, new for Romania and represented by a relatively large population. The article presents a detailed description of its morphological characters, together with the main seasonal characteristics and the coenotic environment in which the species grows there. At the same time, the conservation status of the population and its existing vulnerabilities are evaluated.
\end{abstract}

Keywords: Enisala Nature Reserve, chorology, distinctive characters, conservation status.

\section{Introduction}

The Enisala Nature Landscape Reserve (Fig. 1), from Tulcea County, on the shores of Lake Razelm (Razim), is intended for the conservation of the fossil coastline landscape of the Black Sea [15], being established by Government Decision no. 2151/2004, with an area of 57 ha. It consists in practice of two rocky hills, the hill of Heracleea (Enisala) fortress - in the north-west - and the Sinis Petcu hill - in the south-east. The upper area of the hills, with a maximum altitude of $110 \mathrm{~m}$ and $92 \mathrm{~m}$ respectively, consists of limestones of reef origin, and their base consists of loessoid deposits.

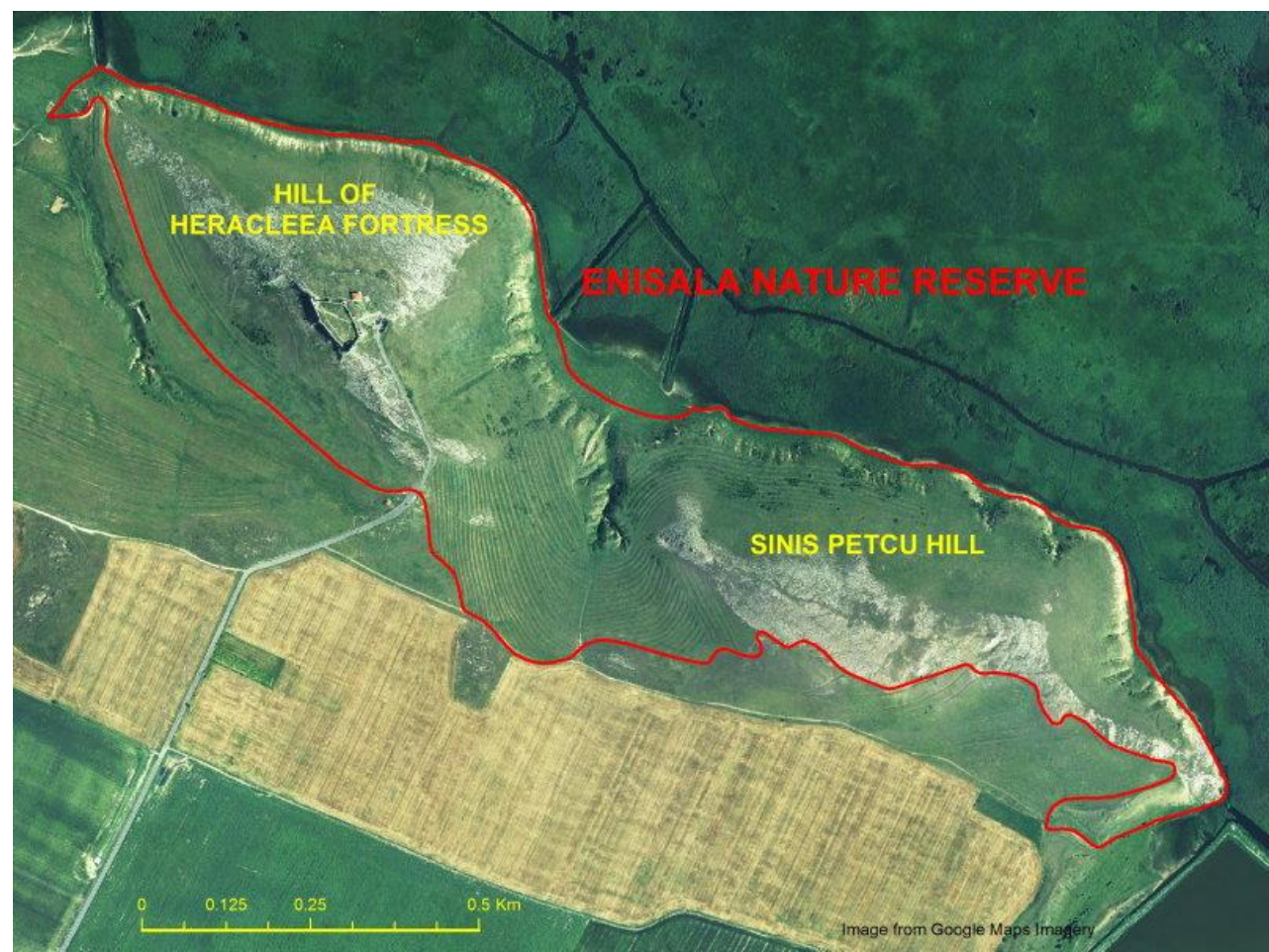

Fig. 1: Image with Enisala Nature Reserve 
Initially the plant species representative for the nature reserve were considered: Euphorbia myrsinites L. subsp. myrsinites, Campanula romanica Săvul. and Dianthus nardiformis Janka. Subsequent floristic research $[14,8]$ has reported other taxa of high scientific value, such as: Achillea clypeolata Sibth. et Sm., Bufonia tenuifolia L., Centaurea salonitana Vis., Centaurea tenuifolia DC., Gagea bulbifera (Pallas) Schultes et Schultes fil., Galium verticillatum Pourret ex Lam., Koeleria lobata (Bieb.) Roemer et Schultes, Minuartia adenotricha Schischkin, Ornithogalum amphibolum Zahar., Scandix pecten-veneris L. subsp. pecten-veneris, Scorzonera mollis Bieb. and Silene exaltata Friv.

In the spontaneous flora of Romania had been recognized so far 22 species of Lathyrus (Fabaceae) [16], a genus distributed from steppe meadows to spruce forests, covering a wide range of ecological conditions.

In the spring of 2021, during some botanical observations made on the Sinis Petcu hill, the species Lathyrus saxatilis (Vent.) Vis. (Fig. 2) was discovered, new for Romania.

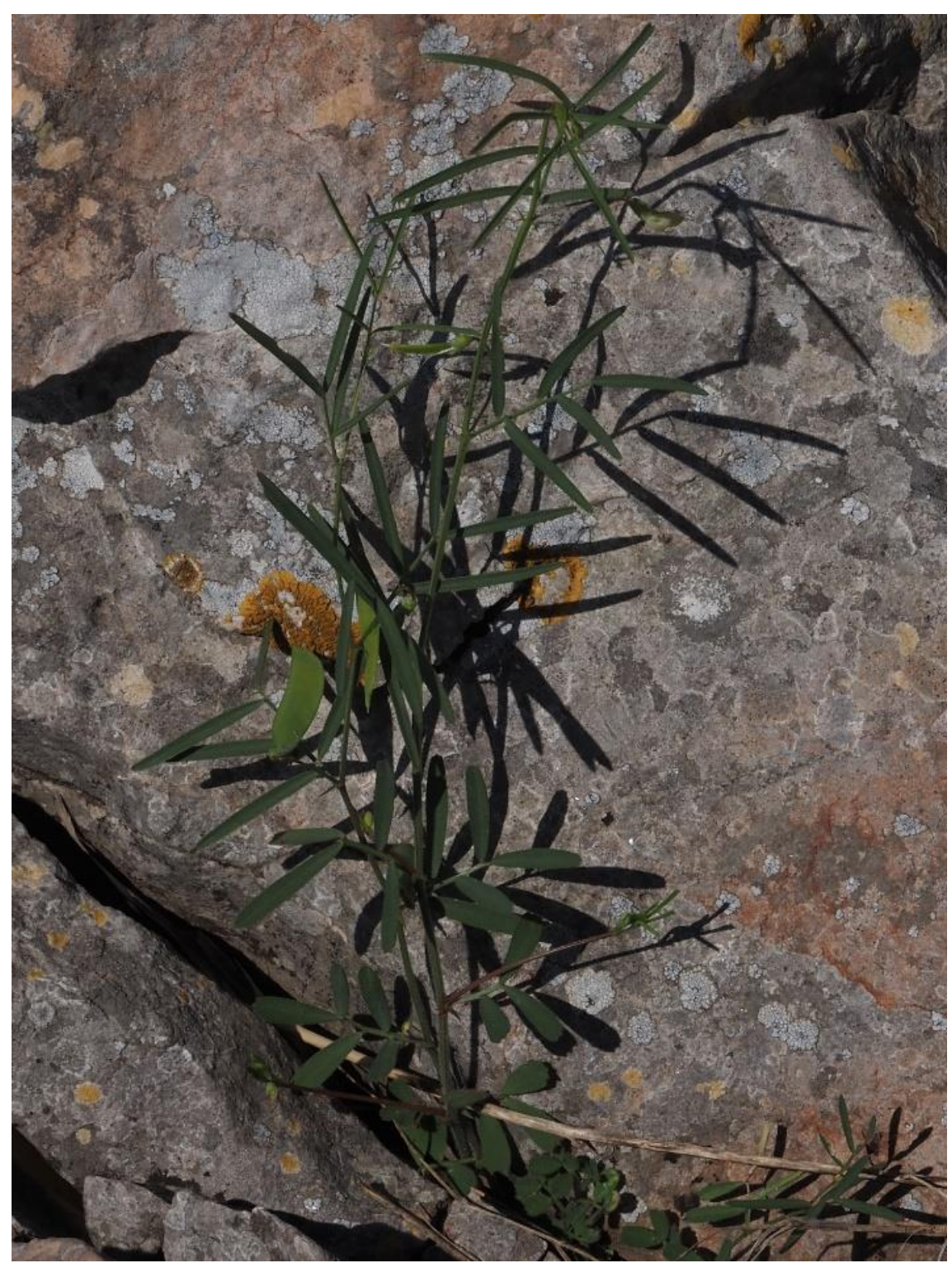

Fig. 2: Photograph of Lathyrus saxatilis 


\section{Materials and Methods}

Between 2 and 9 May 2021, the following field work has been carried out:

- observations were made on the site conditions;

- the area occupied and the number of individuals of Lathyrus saxatilis were evaluated;

- in a place considered representative for the species Lathyrus saxatilis, a phytocoenological relevé was placed, in which the vascular plants on a surface of approximately $100 \mathrm{~m}^{2}$ were determined, establishing at the same time the abundance-dominance index for each species;

- the coordinates of the relevé centre were established, with a terrestrial GPS receiver;

- relevant photos were taken of the species;

- observations and measurements were made on the morphology of Lathyrus saxatilis;

- the conservation status and the vulnerability of the populations of the species were analyzed;

- a specimen of Lathyrus saxatilis was collected and deposited in the Herbarium of the Faculty of Forestry, Brașov (BSV herbarium sheet no. 064709).

The following books were used to determine the species: Flora Europaea, 2 [2], Flora Republicii Populare Romîne V [9]; Plante vasculare din România [16] and Flora ilustrată a României [5].

\section{Results and Discussion}

The species Lathyrus saxatilis (Vent.) Vis. (L. ciliatus Guss., Vicia saxatilis (Vent.) Tropea) has a predominantly Mediterranean distribution, being widespread in Albania, Bulgaria, Crimea, Croatia, France, Greece, Italy, Northern Macedonia, Spain and Turkey [2, 7, 3, 18], and being considered rarer in the eastern part [4]. It is an annual plant, with one or more stems starting from the same base, $10-30 \mathrm{~cm}$ high. The hairiness is accentuated in the lower part of the plant and is obviously reduced to the upper part, which is most often glabrous at maturity. The upper leaves (Fig. 3a) have 1-3 pairs of linear leaflets (1-2 mm wide and 10-30 $\mathrm{mm}$ long), terminated with a short arista (they have no tendril). The lower leaves (Fig. 3b) have obcordate leaflets (3-5 mm wide and 5-10 mm long), with 3 teeth at the apex. The stipules are semi-hastate, 2-3 $\mathrm{mm}$ long, with irregularly toothed lobes. The flowers (Fig. 3c) are solitary, are 6-9 $\mathrm{mm}$ long and have a peduncle of 10-20 mm, articulated in the upper half. The corolla is pale yellow with purple veins and tends to turn violet on drying. The calyx has triangular teeth, slightly shorter than the tube. The legume (Fig. 3d) contains 3-8 seeds, is glabrous, 20-30 mm long and 4-7 mm wide.

The main distinguishing features can be observed as follows:

- pale yellow flowers, solitary, obviously pedunculate;

- leaves without tendrils, the upper with linear leaflets, the basal obcordate, obviously hairy and with 3 teeth at the apex.

The species prefers sunny, rocky or stony places [4], flowering in April-May.

The population on Sinis Petcu hill consists of at least 200-300 plants, spread over a surface of $c .1-1.5 \mathrm{ha}$, in the upper part of the slope with southern exposure, among the limestone rocks and on the stony meadow at their base. The slope of the land is $15-25^{\circ}$. The soil is a rendzinic lithosol. 


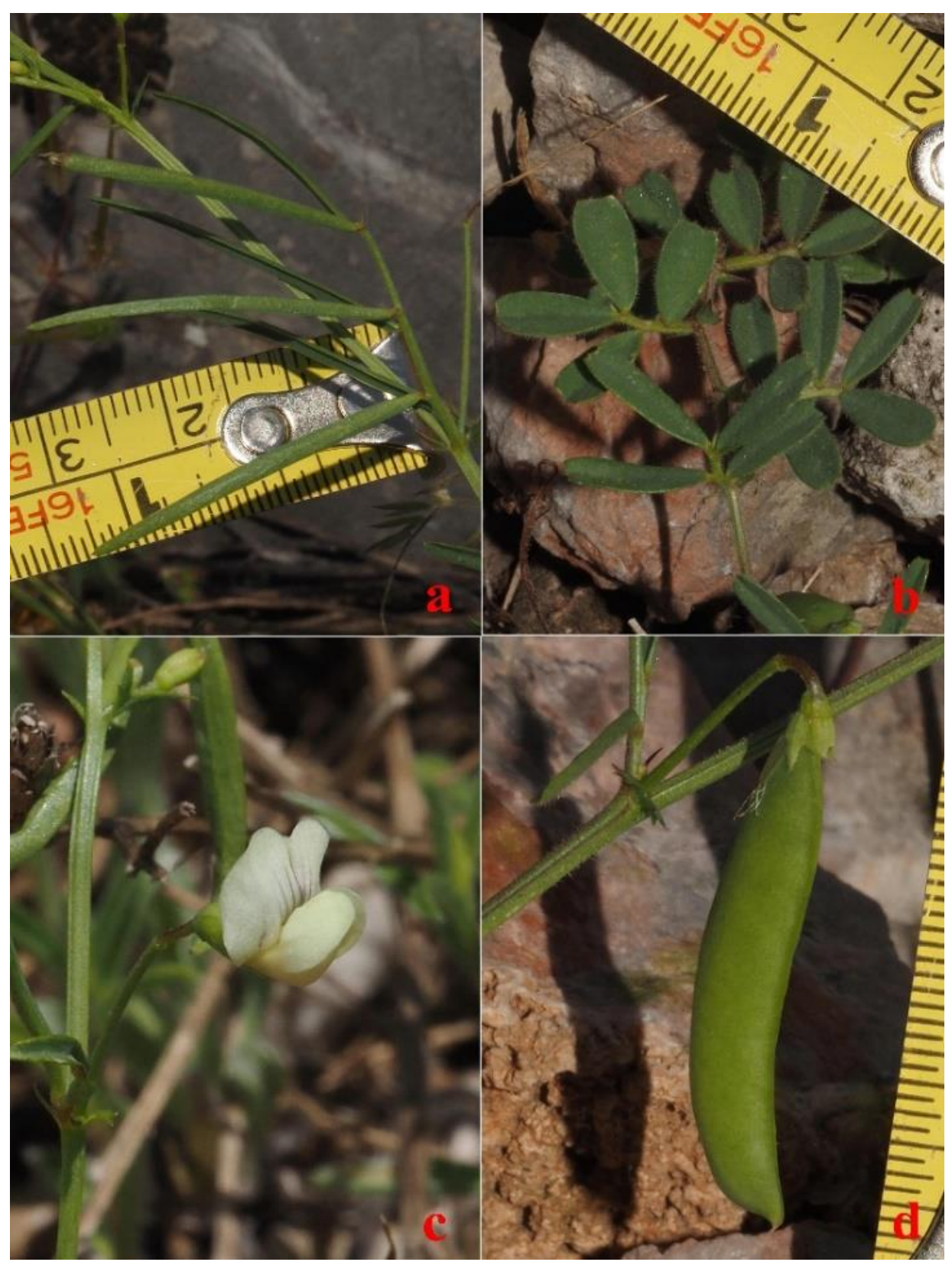

Fig. 3: Photographs of Lathyrus saxatilis - morphological details ( $\mathrm{a}$ - upper leaf, $\mathrm{b}$ - lower leaf $\mathrm{c}$ - flower, $\mathrm{d}$ - legume)

Both the vitality and the conservation status of the species are very good. That said, the vulnerability of the population is high, with the risk of heavy grazing by domestic animals (sheep, goats), as the situation exists currently, at a maximum distance of $100 \mathrm{~m}$, on the northern slope of the Sinis Petcu hill, even inside the nature reserve. In addition, part of the population area exceeds the southern limit of the nature reserve, where there are also two small places from which, a long time ago, stone was extracted. In this context, it would be desirable for the boundary of the nature reserve to be revised so as to include the entire southern meadow of Sinis Petcu Hill, up to the dirt road at the end of the agricultural land, because it has a pronounced natural character (especially in the upper part), preserving many rare plant species.

The species identified in the floristic relevé carried out (date: 09.05.2021, geographical coordinates: N 4452'45.4' E 28 50'42.9", altitude: 75-80 m), are the following: Scandix pectenveneris L. - 2, Alyssum hirsutum Bieb. - 1, Crepis sancta (L.) Bornm. - 1, Geranium pusillum L. 
- 1, Lamium amplexicaule L. - 1, Lathyrus saxatilis (Vent.) Vis. - 1, Poa bulbosa L. - 1, Onosma visianii Clementi - 1, Sedum urvillei DC. - 1, Trigonella monspeliaca L. - 1, Valerianella lasiocarpa (Steven) Betcke - 1, Vicia striata M. Bieb. - 1, Arenaria serpyllifolia L. - +, Camelina microcarpa DC. - +, Cruciata pedemontana (Bellardi) Ehrend. - +, Dianthus nardiformis Janka -+ , Erodium cicutarium (L.) L'Herit. - +, Euphorbia myrsinithes L. subsp. litardierei Font Quer et Garcias Font - +, Galium verticillatum Pourret ex Lam. - +, Lactuca perennis L. - r, Lathyrus setifolius L. - +, Minuartia adenotricha Schischkin - +, Papaver dubium L. - +, Senecio jacobaea L. -+, Thymus zygioides Griseb. - +, Vicia angustifolia L. - +, Viola arvensis Murray - +, Achillea clypeolata Sibth. et Sm. - r, Agropyron ponticum Nevski - r, Allium rotundum L. - r, Anthoxanthum odoratum L. - r, Bromus squarrosus L. - r, Celtis australis L. - r, Centaurea sp. r, Eryngium campestre L. - r, Festuca callieri (Hackel ex St. Yves) Markgraf - r, Fumaria rostellata Knaf - r, Linaria genistifolia (L.) Miller - r, Medicago minima (L.) L. - r, Muscari racemosum (L.) Miller - r, Paronychia cephalotes (Bieb.) Besser - r, Scorzonera mollis M. Bieb. - r, Teucrium chamaedrys L. - r, Trigonella gladiata Steven ex Bieb. - r, Verbascum sp. - r, Veronica chamaedrys L. - r, Veronica hederifolia L. - r.

The vegetation belongs to the Pimpinello - Thymion zygioides Dihoru 1970 alliance, the Agropyro pontici - Thymetum zygioides (Dihoru 1970) Dihoru et Doniță 1970 association.

\section{Conclusions}

In the area of the Enisala nature reserve (Tulcea county), on Sinis Petcu hill, the species Lathyrus saxatilis was discovered, which had not been previously reported in Romania.

It is important that the population is large and the conservation status and vitality are favourable, especially in the context in which the place in question is at the north-eastern limit of the general area of distribution of the species, where its presence is considered rare. In addition, the fact that the population is partially located in a nature reserve is an important premise for its long-term conservation.

These findings prove that detailed botanical studies can still provide important biogeographical information even in generally well-studied areas of Dobrogea, where there are well-preserved natural vegetation stands (unaffected or slightly affected anthropically over time), even if they are small in extent.

Acknowledgements: We would like to thank our friend Adrian Indreica, from the Faculty of Forestry from Braşov, for his useful advice regarding the collection of field data.

\section{REFERENCES}

1. Asmussen, C.B., Liston, A., 1998, Chloroplast DNA Characters, Phylogeny, and Classification of Lathyrus (Fabaceae), American Journal of Botany, 85 (3): 387-401.

2. Ball, P.W., 2005, Lathyrus L. In: Tutin, T.G., Heywood, V.H, Burges, N.A., Moore, D.M., Valentine, H.D., Walters, S.M., Weeb, D.A. (eds.), Flora Europaea, Cambridge University Press, 2: 136-143.

3. Barina, Z., Pifkó, D., 2008, New and interesting floristical records from Albania, Acta Botanica Hungarica, $50(3-4):$ 231-236.

4. Blamey, M., Grey-Wilson, C., 2008, Wild Flowers of the Mediterranean, A \& C Black, London.

5. Ciocârlan, V., 2000, Flora ilustrată a României, Ed. Ceres, București.

6. Cuzic, V., Petrescu, M., 2006, Studiul avifaunei și habitatelor din Podișul Dobrogean în scopul dezvoltării rețelei de arii protejate, Delta Dunării, III: 153-164. 
7. Delipavlov, D., Dimitrov, S., 1973, Beitrag zum Studium der Flora Bulgariens, Feddes Repertorium, 83 (78): 489-493.

8. Făgăraş, M., Bercu, R., 2014, Observations about flora and plant associations from Enisala natural reserve (Tulcea county), Studii și Cercetări, Biologie, Universitatea „Vasile Alecsandri” din Bacău, 23 (1): 90-98.

9. Grințescu, I., Nyárády E.I., 1957, Genul Lathyrus L. In: Săvulescu T. (red. pr.), Flora Republicii Populare Romîne, Ed. Academiei R.P.R., V: 405-445.

10. Kenicer, G.J., Kajita, T., Pennington, R.T., Murata, J., 2005, Systematics and Biogeography of Lathyrus (Leguminosae) based on international transcribed spacer and cpDNA sequence data, American Journal of Botany, 92 (7): 1199-1209.

11. Leth, M., 2009, Phylogeny of Old World Lathyrus L. (Fabaceae) based on morphological data, Fedes Repertorium 120 (1-2): 59-74.

12. Oltean, M., Negrean, G., Popescu, A., Roman, N., Dihoru, G., Sanda, V., Mihăilescu, S., 1994, Lista Roșie a plantelor superioare din România. In: Oltean, M. (coord.), Studii, sinteze, documentații de ecologie, Academia Română, Institutul de Biologie, București, 1: 1-52.

13. Oprea, A., 2005, Lista critică a plantelor vasculare din România. Ed. Universităţii Alexandru Ioan Cuza, Iași.

14. Petrescu, M., 2007, Dobrogea and the Danube Delta flora and habitat conservation, Eco-Museal Research Institute, Bibiloteca Istro-Pontică, Seria Științele Naturii, 2, Tulcea.

15. Petrescu, M., Dinu, C., Cuzic, V., Panait, V., 2006, Arii protejate din Dobrogea propuse de Institutul de Cercetări Eco-Muzeale Tulcea, Delta Dunării, III: 25-40.

16. Sârbu, I., Ştefan, N., Oprea, A., 2013, Plante vasculare din România, Ed. Victor B Victor, București.

17. Sârbu, A., Negrean, G., Pascale, G., Anastasiu, P., 2004, Globally and European threatened plants present in Dobrogea (South-Eastern Romania). In: Gafta, D., Akeroyd, J. (eds.), Nature Conservation Concepts and Practice, Springer: 116-122.

18. Șin, A., Altan, Y., 1990, Karyological studies on some Turkish Lathyrus L. species (L. saxatilis (Vent.) Vis., L. vinealis Boiss. et Noe., L. inconspicuus L., L. setifolius L.), Doğa, Türk Botanik Dergisi, 15 (1): 50-56.

19. Urziceanu, M., Anastasiu, P., Șesan, T.E., 2020, Rare and threatened plants in the area of the wind farm located in Natura 2000 site ROSCI0060 Dealurile Agighiolului (Romania), Acta Horti Botanici Bucurestiensis, 46: 5-33.

\section{LATHYRUS SAXATILIS O SPECIE NOUĂ PENTRU ROMÂNIA}

\section{(Rezumat)}

Cu ocazia unor observații botanice efectuate în primăvara anului 2021, în zona Rezervației naturale Enisala, a fost descoperită specia Lathyrus saxatilis, nouă pentru România, reprezentată printr-o populație relativ numeroasă. Articolul prezintă o descriere detaliată a caracterelor morfologice, alături de principalele caracteristici staționale și ambianța cenotică în care crește specia în locul respectiv. Totodată sunt evaluate starea de conservare a populației și vulnerabilitățile existente. 